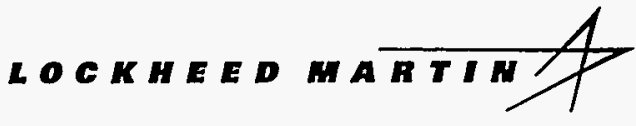

ENVIRONMENTAL RESTORATION PROGRAM
RECEIVED

AUG 201996

OSTI

ORNL/ER-359

\title{
Root Cause Analysis for Waste Area Grouping 1 Batch I, Series 1 Tank T-30 Project at Oak Ridge National Laboratory Oak Ridge, Tennessee
}

This document has been approved by the ORNL Technical Information Office for release to the public. Date: $8 / 12 / 96$

ENERGY SYSTEMS 


\section{DISCLAIMER}

This report was prepared as an account of work sponsored by an agency of the United States Government. Neither the United States Government nor any agency thereof, nor any of their employees, makes any warranty, express or implied, or assumes any legal liability or responsibility for the accuracy, completeness, or usefulness of any information, apparatus, product, or process disciosed, or represents that its use would not infringe privately owned rights. Reference herein to any specific commercial product, process, or service by trade name, trademark, manufacturer, or otherwise does not necessarily constitute or imply its endorsement, recommendation, or favoring by the United States Government or any agency thereof. The views and opinions of authors expressed herein do not necessarily state or reflect those of the United States Government or any agency thereof. 
DISCLAIMER

Portions of this document may be illegible in electronic image products. Images are produced from the best available original document. 


\section{MACTEC}

contributed to the preparation of this document and should not be considered an eligible contractor for its review.

This report has been reproduced directly from the best available copy.

Available to DOE and DOE contractors from the Office of Scientific and Technical Information, P.O. Box 62, Oak Ridge, TN 37831; prices available from 423-576-8401 (fax 423-576-2865).

Available to the public from the National Technical Information Service, U.S. Department of Commerce, 5285 Port Royal Rd., Springfield, VA 22161. 
Energy Systems Environmental Restoration Program

Root Cause Analysis for

Waste Area Grouping 1

Batch I, Series 1 Tank T-30 Project at

Oak Ridge National Laboratory, Oak Ridge, Tennessee

Date Issued-August 1996

\author{
Prepared by \\ MACTEC \\ Oak Ridge, Tennessee \\ under subcontract 22X-HQG60V \\ Prepared for the \\ U.S. Department of Energy \\ Office of Environmental Management \\ under budget and reporting code EW 20 \\ Environmental Management Activities at the \\ OAK RIDGE NATIONAL LABORATORY \\ Oak Ridge, Tennessee 37831-7101 \\ managed by \\ LOCKHEED MARTIN ENERGY SYSTEMS, INC. \\ for the \\ U.S. DEPARTMENT OF ENERGY \\ under contract DE-AC05-84OR21400
}


-.....

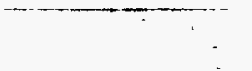




\section{PREFACE}

This root cause analysis for the Waste Area Grouping 1, Batch I, Series 1 Tank T-30 Project at Oak Ridge National Laboratory was prepared to report the results of the root cause analysis, which was conducted to determine reasons for not removing Tank T-30 as had been originally planned. This work was performed under Work Breakdown Structure 6.1.01.21.02 (ADS 3301, Inactive Tanks). Publication of the document meets reporting requirements of Energy Systems' root cause analysis procedure, ESPQA-16.2. This document provides the background, problem statement, results, and methodology for Tank T-30 root cause investigation. The problem investigated was stated as, "Tank T-30 was not removed under a maintenance action as originally planned." The investigation was conducted to identify and, where possible, correct weaknesses to avoid similar delays in future inactive tank remediation projects. 



\section{CONTENTS}

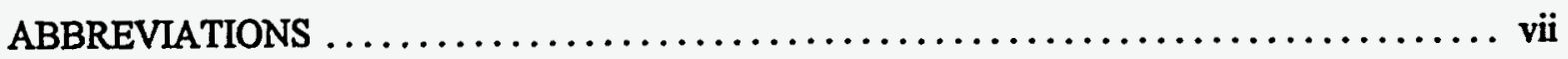

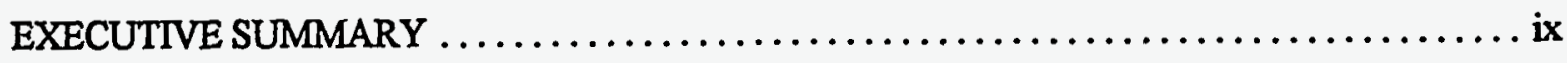

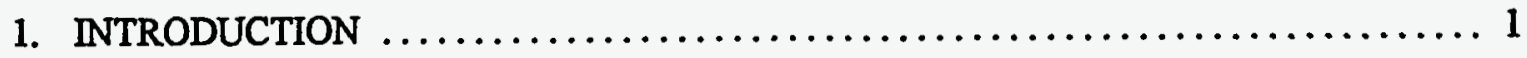

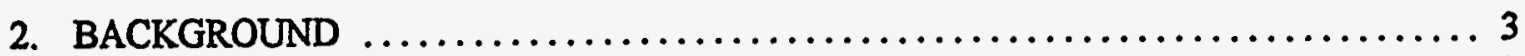

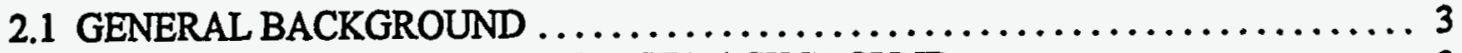

2.2 BATCH I, SERIES I TANK PROJECT BACKGROUND ................ 3

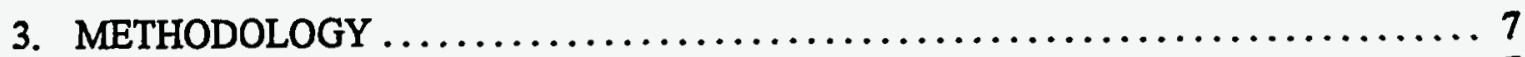

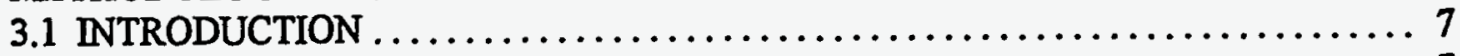

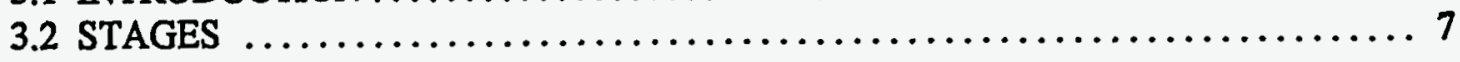

4. ROOT CAUSE ANALYSIS RESULTS AND RECOMMENDATIONS $\ldots \ldots \ldots \ldots \ldots, 9$

4.1 OBJECTIVE, SCOPE, AND STATEMENT OF PROBLEM $\ldots \ldots \ldots \ldots \ldots \ldots \ldots, 9$

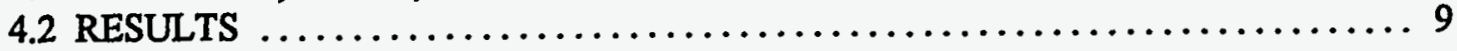

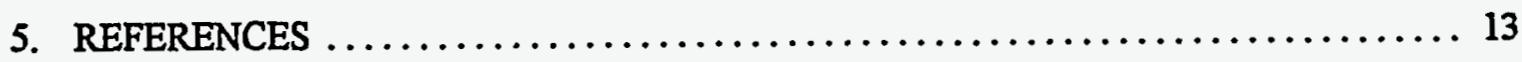




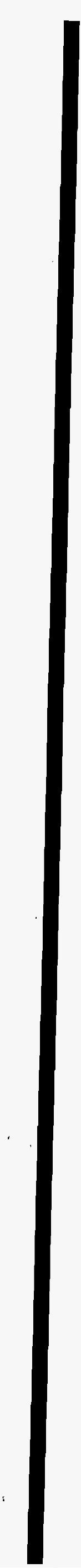




\section{ABBREVIATIONS}

AST Advanced Systems Technology

CERCLA Comprehensive Environmental Response, Compensation, and Liability Act of 1980

DAC derived air concentration

DOT Department of Transportation

FY fiscal year

LLLW liquid low-level waste

ORNL Oak Ridge National Laboratory

SEG Scientific Ecology Group

WCDP waste certification and disposal plan 


\section{EXECUTIVE SUMMARY}

Four inactive liquid low-level waste tanks (LLLW) were scheduled for remedial actions as the Batch I, Series 1 Tank Project during fiscal year 1995. These tanks are 3001-B, 3004-B, T-30, and 3013. The initial tank remediation project was conducted as a maintenance action. One project objective was to gain experience in remediation efforts (under maintenance actions) to assist in conducting remedial action projects for the 33 remaining inactive LLLW tanks. Batch I, Series 1 project activities resulted in the successful remediation of Tanks 3001-B, 3004-B, and 3013. Tank T-30 remedial actions were halted due to information obtained during waste characterization activities. The conditions discovered on Tank T-30 would not allow completion of tank removal and smelting as originally planned.

A decision was made to conduct a root cause analysis of Tank T-30 events to identify and, where possible, correct weaknesses that, if uncorrected, could result in similar delays for completion of inactive tank remediation projects in the future. The objective of the analysis is to determine why a portion of expected end results for the Tank T-30 project were not fully achieved. The root cause analysis evaluates project events and recommends improvements for application to future projects.

Analysis of Tank T-30 events resulted in two root causes. They are as follows:

- RC-1 Tank isotropic distribution had not been determined at the initiation of project planning.

- RC-2 The process for characterizing waste was not well understood at the project planning stage.

Four actions are recommended to prevent future project delays similar to those that occurred with Tank T-30. These recommended corrective actions are as follows:

- Require the inclusion of a waste certification and disposal plan (WCDP) in formal project documentation. The WCDP contains the specific process or processes used to certify the tank waste characteristics and available disposal options.

- Include the WCDP in the list of documents needed for operational readiness assessment or operational readiness review processes. This will ensure complete and traceable determination of waste characteristics and disposal requirements.

- Include a description and a flow chart depicting the waste certification process in existing waste certification procedures. Use this process flow chart for training project managers and engineering personnel associated with tank removal and remediation activities.

- Conduct more extensive analysis of known tank information to develop expected isotopic distributions (with associated confidence limits) for tanks. The calculations serve as a screening tool to determine options for remedial actions and additional sampling requirements. Project plans should include optional disposal and remedial actions as required. 


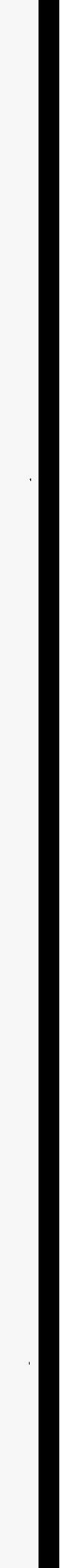




\section{INTRODUCTION}

Four inactive liquid low-level waste (LLLW) tanks were scheduled for remedial actions as the Batch I, Series 1 Tank Project during fiscal year (FY) 1995. These tanks are 3001-B, 3004-B, T-30, and 3013. The initial tank remediation project was conducted as a maintenance action. One project objective was to gain experience in remediation efforts (under maintenance actions) to assist in conducting remedial action projects for the 33 remaining inactive LLLW tanks. Batch I, Series 1 project activities resulted in the successful remediation of tanks 3001-B, 3004-B, and 3013. Tank T-30 remedial actions were halted as a result of information obtained during waste characterization activities. The conditions discovered on tank T-30 would not allow completion of tank removal and smelting as originally planned.

A decision was made to conduct a root cause analysis of Tank T-30 events to identify and, where possible, correct weaknesses that, if uncorrected, could result in similar delays for completion of future inactive tank remediation projects. The objective of the analysis was to determine why a portion of expected project end results for Tank T-30 were not fully achieved. The root cause analysis evaluates project events and recommends beneficial improvements for application to future projects. This report presents the results of the Batch I, Series 1 root cause analysis results and makes recommendations based on that analysis. 



\section{BACKGROUND}

\subsection{GENERAL BACKGROUND}

The Federal Facility Agreement for the Oak Ridge Reservation requires that inactive LLLW tank systems be evaluated and remediated through the Comprehensive Environmental Response, Compensation, and Liability Act (CERCLA) process. The Oak Ridge National Laboratory (ORNL) Inactive Tanks Remediation Program includes 37 tanks in Waste Area Groups 1, 5, 8, and 9. The Gunite and Associated Tanks group are being remediated under separate action.

The 37 tanks in the ORNL Inactive Tanks Remediation Program were screened to establish priorities for tanks to be remediated. Screening criteria considered risk, remediation technologies, interferences with other piping and equipment, location, sludge removal techniques, and storage requirements. Based on the screening, tanks were assigned to one of five batches (I through V) for interim remediation. Further screening was conducted to determine which tanks in each group exhibited similar characteristics such as level of risk, sludge content, and source of LLLW. Four tanks (3001-B, 3004-B, T-30, and 3013) were ultimately selected for remediation as the Batch I, Series 1 tanks.

Prior to the February 8, 1995, regulators' meeting, Batch I, Series 1 tank remediation activities followed the CERCLA process; however, regulators were suggesting that a streamlined CERCLA process could be used for some tanks. Based on discussions at the February 8, 1995, regulators' meeting, a decision was made to remediate the Batch I, Series 1 tanks under a maintenance action. The decision was based on the tank conceptual model, which illustrated that the tanks posed no unacceptable CERCLA off-site risk to human health or the environment. Selected remedial actions and pertinent tank information are presented in Table 1.

\subsection{BATCH I, SERIES 1 TANK PROJECT BACKGROUND}

The Batch I, Series 1 Tank Project team began planning remediation of Tanks 3001-B, 3004-B, T-30, and 3013 as a maintenance action in February 1995 (Energy Systems 1995a, Hepworth, 1995). The plan called for initiating field work in July 1995, with completion prior to the end of FY 1995. All required project documents were prepared, reviewed by subject mater experts, and approved to support the field work.

In April 1995, Advanced Systems Technology (AST) was selected as the subcontractor to perform field work. Before field work began, a readiness assessment was conducted in accordance with the Maintenance Action Readiness Assessment Plan to ensure that all project phases had plans in place that would properly handle or mitigate the impact of unusual events. Operational readiness forms were completed and approved by the readiness review team leader for all readiness plan items.

AST mobilized at Tank 3013 on July 31, 1995, and began field operations in accordance with the project documents. At the onset of the project, minor problems developed, such as not having some supplies and needing to, obtain vehicle permits. These are expected for a new contractor working at ORNL. The issues were handled on a daily basis and Tank 3013 was successfully remediated on August $10,1995$. 
Tank T-30 was the second tank scheduled for field work. AST mobilized at tank T-30 on August 14, 1995. AST found vault and tank contamination levels greater than anticipated. Contamination levels were expected to be lower based on an effort by MK-Ferguson to remove lead shielding bricks and decontaminate the vault and tank. MK-Ferguson had accomplished the maximum lead brick removal and decontamination allowed within the available fixed funding Originally, MK-Ferguson expected to remove 300 to 400 lead bricks; however, 1200 were encountered when the vault was opened. The MKFerguson effort had started well in advance of AST's arriving at the site, and all accessible lead bricks had been removed.

\subsubsection{Tank T-30 Events}

During field work for Tank T-30, three events resulted in reported occurrences. Following is a brief description of each.

- E-1 An AST employee's skin was contaminated (August 16, 1995).

- E-2 Water was released from pipe during cutting, and two employees were sprayed (August 16, 1995).

- E-3 Elevated Cm-244 levels were recorded during welding (August 18, 1995).

\section{E-1 AST Employee Skin Contamination}

On August 16,1995, contamination was found behind the left ear and along the jawline of an AST employee. The contamination was discovered when the employee was preparing to exit the work site. All aspects of the event were properly handled by workers and health physics personnel in accordance with applicable procedures and approved project documents. No procedural violations or inappropriate work practices were observed during the event. This occurrence had no discernable effect on scheduled project activities. The specific cause for the skin contamination was not determined; however, it is reasonable to expect minor contamination under conditions that existed at Tank T-30. A strippable coating was applied to the tent, tank, and vault walls to decrease the potential for additional contamination of personnel. No further actions were warranted. Additional information is contained in Occurrence Report ORO-MMES-ENVRES-1995-0010 (Energy Systems 1995c).

\section{E-2 Water Released from Pipe During Cutting}

A second event also occurred on August 16, 1995. In accordance with the lockout/tagout procedure (Energy Systems 1995e), a pre-job assessment of lines connected to Tank T-30 was conducted. Based on a review of available drawings, tank level history, a facility walkdown, and discussions with facility operations, it was determined that a lockout/tagout was not required. Conditions surrounding the review included the following considerations:

- T-30 had been inactive since 1980 .

- T-30 was emptied in 1993 with no recorded level increases since that time.

- All lines fromT-30 led to Building 4507.

- Building 4507 contained no active systems.

The above conditions provided an additional indication that lines were not active. Thus, the review led to the conclusion that all lines should be safely configured for cutting. 
A bandsaw was used when line-cutting operations began. During cutting operations on a tank cooling jacket line, water sprayed from the line when the pipe wall was breached. Two workers were sprayed during the incident. Workers exited the tank vault. A lockout/tagout was initiated to determine and isolate the source of water. Work was halted until the source of water could be detected and isolated. Prior to the time that the source was isolated, the flow of a small stream of water from the cut line continued to decline indicating a source that was not pressurized. Analysis showed the water was not contaminated and posed no health or safety problem. During this event, proper procedural requirements were observed. An analysis of this event is currently being performed to determine root causes and provide recommended corrective actions. Additional information is in Occurrence Report ORO-LMES-X10ENVRES-1995-0002 (Energy Systems 1995d).

\section{E-3 Elevated Cm-244 Levels Recorded During Welding}

The third event occurred on August 18, 1995. It involved elevated airborne Cm-244 levels due to welding operations. The derived air concentration (DAC) levels increased from $<1 \mathrm{DAC}$ to $231 \mathrm{DAC}$ while welding was taking place. Work was halted by health physics personnel until engineering controls could be put in place. On August 21, 1995, DAC readings were taken before workers entered the work area. The concentration was $0.6 \mathrm{DAC}$. Health physics judged that powered air purifying respirator (Level C) protection was adequate for planned tank removal operations. Work resumed after high efficiency air particulate filters were installed with trunk lines over the weld area to reduce DAC levels. DAC levels once again increased from $<1 D A C$ to $74 \mathrm{DAC}$, and work was suspended. Work was not resumed until personnel protective equipment was upgraded to Level B (supplied air). Seven workers were placed on a bioassay program. (The program ultimately indicated five workers received a committed effective dose equivalent greater than $100 \mathrm{mrem}$.) During the event, all applicable procedures and plans were executed properly; no personnel errors were evident, and personnel were wearing appropriate personal protective equipment as prescribed by health physics. The occurrence report investigation concluded that $\mathrm{Cm}-244$ exhibits a previously unreported migration/release when subjected to heat from welding. As a result, lessons learned specify supplied air or equivalent respiratory protection for welding when $\mathrm{Cm}-244$ is known or suspected. Occurrence Report ORO-LMES-X10ENVRES-1995-0003 (Energy Systems, 1995b) provides additional information on this event.

\subsubsection{Tank T-30 Root Cause Analysis Events}

The following sequence of events led to halting of Tank T-30 removal. These events form the framework of the root cause analysis.

Subsequent to events described in Sect. 2.2.1, tank removal activities continued. All lines were successfully cut and capped. In late August 1995, planned waste certification activities were initiated. Based on a tank internal gamma survey and tank liquid analytical data (from sampling conducted in 1988), an analysis was performed to determine tank isotopic distribution for waste certification purposes. Results of the analysis indicated that the waste acceptance criteria for smelting at Scientific Ecology Group (SEG) were exceeded and that the waste would require a Department of Transportation (DOT) Type B container if off-site transportation were required. Only a Seland (not a DOT Type B) container was positioned at the job site. Table 2 identifies the SEG waste acceptance criteria limits and DOT limits compared with tank analysis results. Tank T-30 removal operations were halted on September 14, 1995. At this time, a crane was attached to the tank, and workers were awaiting approval to place the tank in the on-site Sealand container for off-site shipment. After tank removal was halted, swipe surveys were conducted on the insides of the tanks. The analytical results were used to determine tank isotopic distribution for waste certification purposes. This evaluation confirmed previous analytical results that a DOT Type B container would be required and that SEG waste acceptance criteria were exceeded. 
Table 2. Waste acceptance criteria and DOT shipping limits

\begin{tabular}{lll}
\hline \multicolumn{2}{c}{ SEG waste acceptance criteria (metal melt) } \\
Criteria & Limit & Concentration in T-30 \\
Total all nuclides not listed below & $2.0 \mathrm{E}-03 \mathrm{uCi} / \mathrm{gm}$ & $2.4 \mathrm{uCi} / \mathrm{gm}$ \\
$\mathrm{H} 3$ & $1.0 \mathrm{E}-05 \mathrm{uCi} / \mathrm{gm}$ & not present \\
C14 & $3.0 \mathrm{E}-05 \mathrm{uCi} / \mathrm{gm}$ & not present \\
I129 & $1.0 \mathrm{E}-07 \mathrm{uCi} / \mathrm{gm}$ & not present \\
Ra226 & $1.0 \mathrm{E}+01 \mathrm{nCi} / \mathrm{gm}$ & not present \\
TRU & $1.0 \mathrm{E}+00 \mathrm{nCi} / \mathrm{gm}$ & $1.56 \mathrm{E}+02 \mathrm{nCi} / \mathrm{gm}$ \\
& & \\
Element & DOT subtype fraction & \\
Pu239 & Limit & Tank T-30 value \\
Cm244 & 1 & 36 \\
Pu238 & 1 & 427 \\
Eu154 & 1 & 61 \\
Eu155 & 1 & 0.0128 \\
Np239 & 1 & $1.7 \mathrm{E}-04$ \\
Am243 & 1 & $7.32 \mathrm{E}-04$ \\
Co60 & 1 & 3.43 \\
\hline & 1 & $1.74 \mathrm{E}-04$ \\
\hline
\end{tabular}

DOT subtype fractions are unitless numbers derived from a ratio of the $49 \mathrm{CFR} 173.435$ (A2 values) to actual tank concentrations. Any value greater than 1 exceeds the $A 2$ value by that factor and requires use of a Type $B$ shipping container.

After work on Tank T-30 was halted, work was transferred to Tank 3001-B and then to 3004-B, both of which were successfully removed and shipped for smelting. 


\section{METHODOLOGY}

\subsection{INTRODUCTION}

The methodologies described in this section conform with Energy Systems' procedure for root cause analysis (1995f).

A root cause is defined as the most basic reason for an event that, if corrected, will prevent recurrence. Determining a root cause involves a series of steps or stages to provide proper evaluation of the event in question.

An important function of root cause analysis is to evaluate events in sufficient depth to avoid "placing blame" The final result of a root cause analysis is the implementation of corrective actions to prevent recurrence

Prior to initiation of the formal root cause investigation, a kick-off meeting was held with key project personnel for the purpose of outlining the root cause process.

\subsection{STAGES}

Five stages were used in conducting the Tank T-30 root cause analysis. They are (1) identification of the problem; (2) collection of information; (3) organization and analysis of the information; (4) identification of causal factors/root causes; and (5) development of corrective actions.

\subsubsection{Identification of the Problem}

A problem statement is developed prior to beginning the investigation process to focus the scope of an investigation. A well formulated problem statement should meet the following guidelines.

- Be positive. Ensure that the problem stated is really a problem and not a solution.

- State the effect. Emphasize what is wrong not why it is wrong.

- Be specific. Avoid broad or ambiguous concepts.

\subsubsection{Collection of Information}

Collection of information for the problem being investigated is the cornerstone of root cause analysis. Collection of information for Tank T-30 investigation involved the following methods.

- Obtaining relevant procedures and reports.

- Interviewing personnel involved in the project.

- Obtaining relevant project records such as log books, meeting notes, letters, specifications, and plans.

Collection of information included: interviewing 13 persons involved in the project, reviewing project documents, and reviewing personal notes from selected personnel interviewed. 
A summary of documents obtained and reviews, as well as a list of personnel contacted, is provided in Sect. 5.

\subsubsection{Organization and Analysis of Information}

Organization of information is required to avoid confusion of facts, events, and information. In conducting the Tank T-30 investigation, a time line was used to establish the sequence of events for the project. The time line was used to assist in collection of information and to provide a clear picture of how events evolved. After an initial time line is initiated, addition of conditions relative to events provides more detailed account of the event. The time line is a dynamic tool in conducting root cause analysis. As additional information is obtained, it is added to the time line.

\subsubsection{Identification of Causal Factors/Root Causes}

A cause-and-effect diagram is prepared to identify root causes. Cause-and-effect diagraming starts with the most significant event. Next, the cause of the event is listed, and this cause then becomes the next event to be evaluated. This process is continued until no other causes can be found, at which time the root cause has been determined. The methods used to determine root causes help in organizing information to assist in logical thinking.

\subsubsection{Development of Corrective Actions}

Corrective actions to prevent recurrence are developed after all root causes have been identified. Corrective actions must meet the following criteria in order to be valid.

- Prevent recurrence.

- Be within Energy Systems' control.

- Allow Energy Systems to complete its missions. 


\section{ROOT CAUSE ANALYSIS RESULTS AND RECOMMENDATIONS}

\subsection{OBJECTIVE, SCOPE, AND STATEMENT OF PROBLEM}

The objective of the root cause analysis for Tank T-30 is to identify and, where possible, correct weaknesses that, if uncorrected, could result in delays in completing future inactive tank remediation projects. The scope of the root cause analysis covers only Tank T-30 and the project events including events discussed in Sect. 2.2.1.

\section{Problem Statement}

The problem to be addressed by the root cause analysis is as follows:

Tank T-30 was not removed under a maintenance action as originally planned.

The evaluation requested for Tank T-30 is directed at project end results. It is important to determine which events (if any) led to the problem of concern, halting of tank removal operations. The problem description allows a broad investigation while maintaining focus on the problem of concern. The project events that were root causes leading to halting of tank removal operations are to be determined from this problem statement.

The problem-SEG waste acceptance criteria were exceeded-is encompassed by the problem description.

\subsection{RESULTS}

\subsubsection{Root Causes}

Two root causes were identified as the basic reason for not achieving remediation of Tank T-30 as delineated in the original project plan.

RC-1 Tank isotopic distribution had not been determined at the initiation of project planning.

RC-2 The process for characterizing waste was not well understood at the project planning stage.

The investigation of Tank T-30 required collecting and evaluating as much relevant project information as could be obtained in a reasonable time. Information collected was evaluated to provide a clear picture of events that led to halting of tank removal operations. Based on the evaluation, a causeand-effect diagram was developed to determine two root causes. The preceding chapter described the methodology used for root cause analysis. 
Figure 1 is a cause-and-effect diagram depicting the events that were evaluated to determine the root cause for not achieving removal of Tank T-30 as originally planned. The most significant event, "Tank T-30 Removal Halted," is listed on the left. The cause of the event, "Decision to Stop Tank T-30 Removal," is listed on the right. Given a cause, the question becomes, "If the cause had been eliminated, would that have prevented analysis of the effect?" If the answer is "yes," the cause has been found. The identified cause then becomes the next effect or set of effects, and this process is repeated until the root cause(s) has been identified. Repeating the process described above resulted in two root causes, which are identified on Fig. 1 by RC-1 and RC-2.

A thorough evaluation of project events determined that the reported occurrences described in Sect. 2.2.1 did not contribute to halting of tank removal operations. As previously noted, the crane was attached to the tank in a position that allowed it to be removed and placed in the Sealand container for shipping when the operation was halted. Because the reportable events did not contribute to the problem's being investigated, other project events were identified as leading to halting of Tank T-30 removal.

$\mathrm{RC}-1$ resulted in the discovery that the SEG waste acceptance criteria for smelting were exceeded (see Table 2 for limits).

RC-1 also led to the discovery that a DOT Type B shipping container would be required for transport of the tank to any off-site location. At the time of RC-1 discovery, approved and issued project plans assumed the waste acceptance would be met and that a Sealand container was adequate.

RC-2 generated the following results: (1) no alternate remediation plan was incorporated in project documents and (2) a DOT Type B container was unavailable

Both root causes contributed to the decision to halt removal of Tank T-30. (During the project development stage, alternate remedial actions, such as filling T-30 with grout, were frequently discussed. Because of confidence that tank removal and smelting would be successful, alternative remedial actions were not formally included in project documents.)

\subsubsection{Recommendations}

Several changes in processes, training, or procedures are required to prevent future situations such as occurred with Tank T-30.

- Require inclusion of a waste certification and disposal plan (WCDP) in formal project

documentation. The WCDP contains the specific process or processes used to certify the tank waste characteristics and disposal options available.

- Include the WCDP in the list of documents needed for operational readiness assessment or operational readiness review processes. This ensures a complete and traceable determination of waste characteristics and disposal requirements.

- Include a description and a flow chart depicting the waste certification process in existing waste certification procedures. Use this process flow chart for training project managers and engineering personnel associated with tank removal/remediation projects.

- Conduct more extensive analysis of known tank information to develop expected isotopic distributions (with associated confidence limits) for tanks. The calculations serve as a screening tool to determine options for remedial actions and additional sampling requirements. Project plans should include optional disposal/remedial actions as required. 


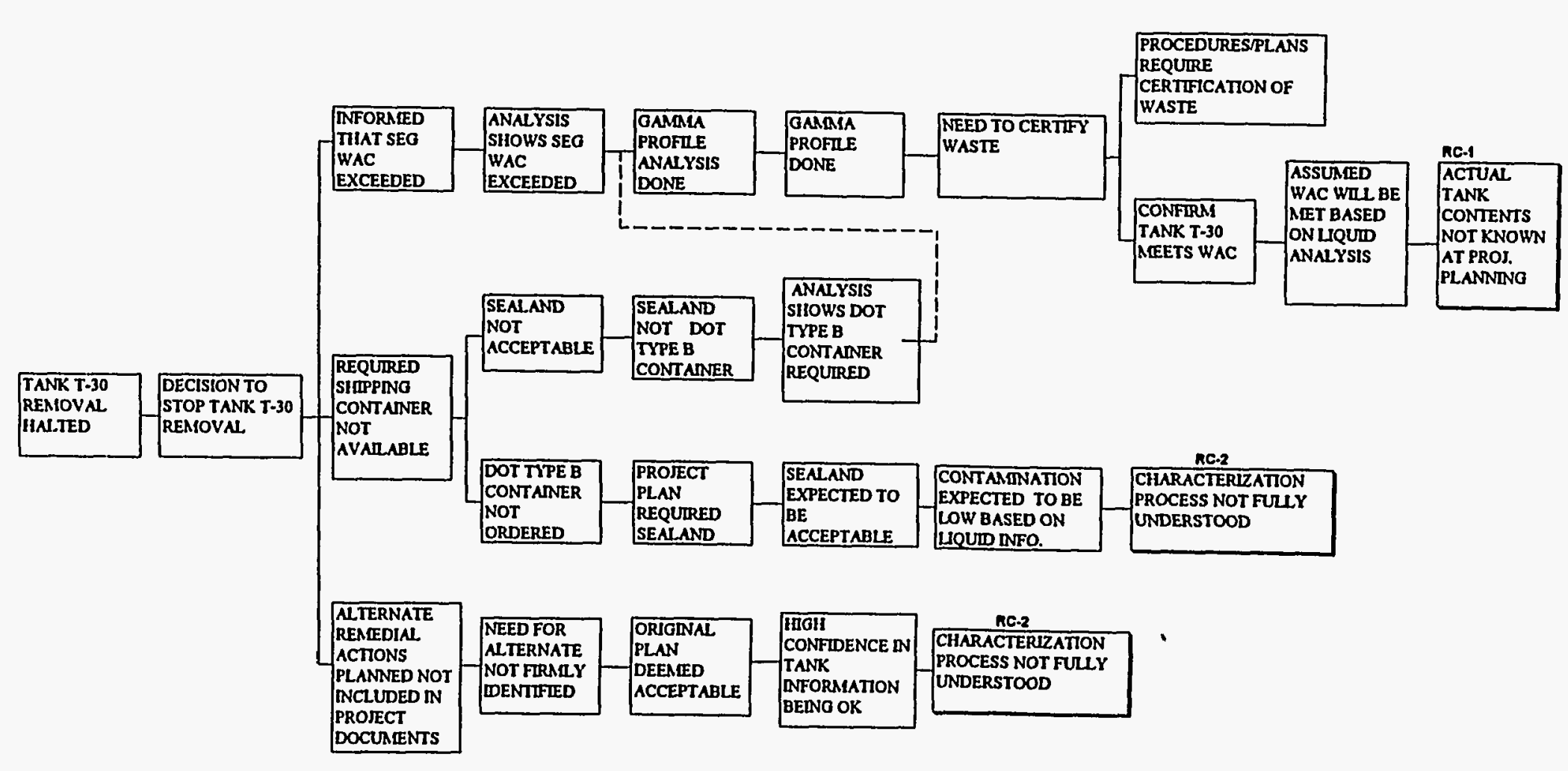

WAC $=$ WASTE ACCEPTANCE CRITEPA

Fig. 1. Tank T-30 Cause and Effect Diagram. 


\subsubsection{Contributing Factors}

The following single contributing factor was observed for Tank T-30 events:

- Communication of expectations between organizations was not sufficient and was not well documented. Communication is a factor in the conduct of any project, and substantial communication did occur on the Batch I, Series 1 Tank Project. Well-documented project meetings were held on a routine basis. 


\section{REFERENCES}

Energy Systems. 1995a. WAG 1 Inactive Tanks (Batch I, Series 1) meeting notes. March 1995 through September 1995.

Energy Systems. 1995b. Occurrence Report ORO-LMES-X10ENVRES-1995-0003, Personnel Internal Radiation Exposure.

Energy Systems. 1995c. Occurrence Report ORO-MMES-ENVRES-1995-0010, Personnel Contamination South of ORNL Building 4507.

Energy Systems. 1995d. Occurrence Report ORO-LMES-X10ENVRES-1995-0002, Pressurized Process Water Line Cut During T-30 Tank Removal Project.

Energy Systems. 1995e. Martin Marietta Energy Systems Inc. Oak Ridge National Laboratory Industrial Safety Procedure, Lockout/Tagout of Hazardous Energy Sources, IS-8.1, Rev. 2, August 27.

Energy Systems. 1995f. Martin Marietta Energy Systems Inc. Procedure, Root Cause Analysis, Number ESP-QA-16.2, Rev. 1, March 12, 1992.

Hepworth, H. K. 1995. Inactive Tanks Program Project Notebooks, Vols. 1 and 2. 


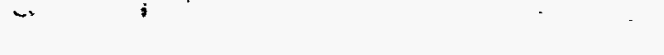




\section{DISTRIBUTION}

1. L. V. Asplund

2. C. A. Bednarz

3. W. D. Brickeen

4. A. J. Kuhaida, Jr.

5. D. L. Garrett

6. D. M. Matteo

7-8. P. T. Owen

9. P. A. Schrandt

10. M. L. Whitehead

11. Central Research Library

12. ER Document Management Center-RC

13-14. Office of Scientific and Technical Information, P. O. Box 62, Oak Ridge, TN 37831

15. M. Boothby, Mactec, 189 Lafayette Dr., Suite C, Oak Ridge, TN 37830 